\title{
Myths and Realities of 'Global' English
}

\author{
Phillipson, Robert
}

Document Version

Accepted author manuscript

Published in:

Language Policy

DOI:

10.1007/s10993-016-9409-z

Publication date:

2017

License

Unspecified

Citation for published version (APA):

Phillipson, R. (2017). Myths and Realities of 'Global' English. Language Policy, 16(3), 313-331.

https://doi.org/10.1007/s10993-016-9409-z

Link to publication in CBS Research Portal

\section{General rights}

Copyright and moral rights for the publications made accessible in the public portal are retained by the authors and/or other copyright owners and it is a condition of accessing publications that users recognise and abide by the legal requirements associated with these rights.

Take down policy

If you believe that this document breaches copyright please contact us (research.lib@cbs.dk) providing details, and we will remove access to the work immediately and investigate your claim. 


\section{Myths and Realities of 'Global' English Robert Phillipson}

Journal article (Post print version)

CITE: Myths and Realities of ‘Global' English. / Phillipson, Robert. In: Language Policy, 21.06.2016.

The final publication is available at Springer via http://dx.doi.org/10.1007/s10993-016-9409-z

Uploaded to Research@CBS: September 2016 


\title{
Myths and realities of 'global' English
}

\section{Robert Phillipson ${ }^{1}$}

\begin{abstract}
The expansion of English worldwide tends to be both seen and marketed uncritically, as a universally relevant lingua franca and medium of education. The post-1945 expansion of English was a deliberate policy of the US and UK governments, foreseen in a speech by Churchill. Elsewhere Churchill endorsed university academic freedom and autonomy, which neoliberal forces currently constrain. Imperial languages are promoted by means of linguicism, which many contemporary policies exemplify. Increased use of English results in a macrosociolinguistic tension between national linguistic capital accumulation or dispossession. European colonisation was legitimated by the fraudulent myth of terra nullius. Americanisation worldwide is furthered by projecting US norms and lifestyle as a cultura nullius for all. English is marketed as a lingua nullius, for instance in British promotion of English worldwide, as though English is a universal 'basic skill'. This is false argumentation that echoes colonial discourse. Privileging English intensifies the gaps between the world's haves and have-nots. This is also now in effect in the countries of the European Union. Critical scholarship is needed to connect macro-level analysis with micro-level conceptual myth-making promoting global English.
\end{abstract}

\section{KEYWORDS}

academic freedom; British Council; global English; imperialism; linguicism; linguistic capital; terra nullius

Language has always been the handmaiden of empire. Antonio de Nebrija, $1493^{2}$

Contrary to the wording affirmed in the Bologna Declaration, the reform of higher education serves the purpose of replacing the linguistic and cultural diversity of Europe by an English linguistic monopoly.

Hans Joachim Meyer, $2011^{3}$

\footnotetext{
${ }^{1}$ I am sincerely grateful for suggestions for improving an earlier version of this article from the journal's reviewers and editors, Hartmut Haberland, and Tove Skutnabb-Kangas.

2 'Siempre la lengua fue compañera del imperio'. In Prólogo a la Gramática de la lengua castellana en http://www.antoniodenebrija.org/prologo.html. All translations are mine.
} 
English: the language of higher education in Europe... it seems inevitable that English, in some form, will definitely become the language of higher education.

James Coleman, $2006^{4}$

... it seems to me indisputable that Global English is becoming the lingua franca of Christianity in the twenty-first century.... contemporary language globalization is somehow related to the amazing Christian revival that we see worldwide.

Zoltán Dörnyei, 20095

.... the English used as an international scientific language is not a lingua franca, a non-language. English is a completely normal language with its specific monolingual semantics, like all other languages. [...] It is the bearer, like all other natural languages, of a particular vision of the world. Jürgen Trabant, $2012^{6}$

How can we counteract the abuse of power that is intrinsic to linguistic hegemony? (...) we need to reflect on this model so as to see if and how it is possible to go along with using English without the risk of being anglicised into its conceptual structures, without being brainwashed by its linguistic patterns.

Pierre Bourdieu, $2001^{7}$.

L'alternative est claire, en effet, bien qu'elle soit très rarement perçue : ou bien accepter l'une ou l'autre des fonctions sociales que la nouvelle définition sociale impartit aux producteurs culturels, celle de l'expert, chargé d'assister les dominants dans la gestion des "problèmes sociaux", ou celle du professeur, enfermé dans la discussion érudite de questions académiques; ou bien assumer efficacement, c'est-à-dire avec les armes de la science, la fonction qui fut remplie longtemps par l'intellectuel, à savoir d'intervenir sur le terrain de la politique au nom des valeurs ou des vérités conquises dans et par l'autonomie.

Pierre Bourdieu, 19898.

\footnotetext{
3 "Entgegen dem Wortlaut der Bologna-Erklärung dient also die Studienreform dem Ziel, die dort beschworene sprachliche und kulturelle Vielfalt Europas durch ein englisches Sprachmonopol zu ersetzen" (Meyer 2011: 61).

${ }^{4}$ In a survey article on English-medium teaching in European higher education (2006:11). For further examples, see Phillipson 2015.

${ }^{5}$ From an anthology probing the links between the worldwide English teaching industry (TESOL) and contemporary Christian missionary organisations, pages 156 and 157 in Wong and Canagarajah 2009.

${ }^{6}$ From a book on the future of German as a scholarly language, see Oberreuter et al, eds., 2012: 108.

7 'Comment lutter contre ces abus de pouvoir linguistiques qu'autorise l’hégémonie linguistique et contre l'impérialisme symbolique ?... Et il faut réfléchir sur ce modèle pour voir si et comment il est possible d'accepter l'usage de l'anglais sans s'exposer à être anglicisé dans ses structures mentales, sans avoir le cerveau lavé par les routines linguistiques.' (Bourdieu et al. 2001: 47-48).
} 
These appetisers from the scholarly literature are by a pioneer Spanish linguist with imperial ambitions (Nebrija), a worried German former Minister of Education (Meyer), a British language policy specialist (Coleman), a Hungarian applied linguist who believes in uniting the Christian gospel with the doctrine of global English (Dörnyei), a Romance-language scholar in Germany who now has to teach through the medium of English (Trabant), and an influential French sociologist who advocates competence in English without being brainwashed, and considers that academia should not be coopted into uncritically performing tasks for those in power, nor remain ensconced in an ivory tower, but should use the achievements of scholarly knowledge acquired through university freedom and autonomy in committed socio-political activity (Bourdieu).

These extracts capture some of the key challenges in analysing the role of language in the contemporary world, and the role of English in particular. Is global English a necessary panacea? Or is global English a myth, a project behind which there are strong forces and identifiable agents with clear commercial and geopolitical agendas? Is English the medium for global Americanisation since 'the chief business of the American people is business' (President Calvin Coolidge, $1925^{9}$ )? Can this global thrust be compatible with the interests and rights of other peoples and speakers of other languages in a volatile capitalist system? How can academics remain critical intellectuals generating expertise that addresses serious social and political challenges?

The citations serve to show how important it is to understand the forces behind changes to the global linguistic mosaic, their historical origins, and where we are heading, wittingly or unwittingly. Answering the questions, which are fundamental to the analysis of language policy, and of why some languages thrive while others are marginalised, presupposes a trans-disciplinary approach that can clarify processes in the hierarchisation of languages, and relate them to shifting language ecologies nationally and internationally. The language policy challenges dovetail with issues of social justice and cultural diversity at the individual and the group level.

The article demonstrates how English is now marketed as a language that everyone needs and that all should learn. This is one of the myths of global English. It is blithely proclaimed as the lingua franca of science, of business, of European integration, and of international understanding as though no other languages serve such purposes. English is fraudulently projected as a deterritorialised language that is disconnected from its original sources and even from the driving forces behind its expansion worldwide. English is promoted as if it played no role in intensifying the global and local gaps between haves and have-nots, the obscenely rich in North and South countries and the Majority World. Globalisation itself is a false universalism (Bourdieu 2010). Global English needs to be understood as a project behind which there are identifiable agents.

It is also relevant to point out that use of my source material presupposes proficiency in Spanish, German, and French, as well as English, including input

\footnotetext{
8 The citation is in the original French (Bourdieu 1989: 486) as a reminder that the vocabulary of French and English have many roots in common. The essence of the citation is covered in the opening paragraph following the citations.

9 This quote is often cited incorrectly as 'The business of America is business', see http://www.thisdayinquotes.com/2010/01/business-of-america-is-business.html.
} 
from scholars worldwide. Understanding what is happening in the Nordic countries (Scandinavia and Finland), where I happen to live, requires proficiency in Scandinavian languages and Finnish. There is a considerable body of language policy analysis in these languages, only some of which has been written up in English. The idea that all relevant scholarship is in English is another of the myths of global English. The modern world has abandoned Goethe's principle of texts in all languages enriching humanity and the individual ${ }^{10}$ :

Wer fremde Sprachen nicht kennt, weiß nichts von seiner eigenen.

People who know no foreign languages know nothing of their own.

This has been replaced by a third global English myth, namely that in international communication the only language you need is English, as expressed in my update of Goethe's maxim:

Wer Englisch kennt, braucht keine anderen Sprachen.

\section{Whoever knows English has no need of other languages.}

After introducing the main themes of the article, a historical section clarifies how 'global' English came into existence in the mid-20 th century. The following section analyses the transition from the terra nullius ideology that sought to justify the occupation by Europeans of territory worldwide, to the adoption in recent decades of neoliberal economic policies in synergy with processes of worldwide Americanisation, the projection and internalisation of US norms as a cultura nullius of universal relevance. A key constituent of this transition is the current marketing and uncritical acceptance of English as a lingua nullius, the myth that English is ideologically neutral, serves all equally well, and should therefore be learned and used universally. Key concepts for exploring shifts in the global language ecology are linguistic capital accumulation and dispossession. A concluding section stresses the importance of academic freedom for maintaining a healthy balance between an increased use of English and the maintenance of linguistic diversity.

I need to stress that I have nothing against English when used appropriately, in education and elsewhere, when it is not displacing other languages - a topic that I shall return to - but in addition to English serving countless useful purposes in the modern world, English has been and is being misused. This is therefore an issue that urgently needs addressing. Many languages function as linguistic hegemons (Arabic, Chinese, French, Russian, Turkish, etc.), but English is currently the most prevalent one. A historical perspective is needed.

\section{The historical record: terra nullius and the invention of global English}

The global Europeanisation process dates back to the policies of the Spaniards and Portuguese six centuries ago, the Christianising mission with a Papal blessing, and the quest for gold and territory, after the expulsion of Islam from

10 Maximen und Reflexionen, Aus Kunst und Altertum, 1821. 
the Iberian peninsula11. In Mexico 'The locals who could not understand Spanish were considered subhuman, and so could be subjugated forthwith... reaching far beyond anything Nebrija imagined when he commented on language and empire going together' (Errington 2008: 25-26). Europeans violently took over the territories of other peoples on all continents and to a large extent eliminated their cultures and languages.

The English philosopher John Locke, in Two treatises of government (1698), provided a rationalisation for Europeans arrogating to themselves a Christian God-given right to occupy territory elsewhere. Land in what became named the Americas was terra nullius, land supposedly belonging to no-one, to which its benighted inhabitants had no claim or rights ${ }^{12}$. The ideological foundation for this argument is the dichotomy between Us ('civilised') and Them ('barbarians') that has been deeply rooted in the thinking of the Western world and other cultures since the time of the ancient Greeks.

The historical record reveals that in the UK, as in other European countries and the USA, a systematic effort over centuries went into attempts to convert a multilingual reality into a monolingual state, and to pursue the same goal worldwide by means of linguistic imperialism (Phillipson 1992, 2009). The essential process involved was linguicism, which functions in analogous ways to racism, sexism, and classism: 'ideologies, structures and practices which are used to legitimate, effectuate, regulate and reproduce an unequal division of power and resources (both material and immaterial) between groups which are defined on the basis of language' (Skutnabb-Kangas 1988: 13). Most education systems for Indigenous peoples and minorities worldwide reflect linguicism (SkutnabbKangas 2000).

Laissez-faire social and economic doctrine emerged in the 17 th century and was canonised in the 19th as an endorsement of individualism in the age of 'free' trade. Christian faith and political philosophy were seen as confirming laissezfaire capitalism and individualism (see Keynes 2015, 39-61, originally written in 1926). In the European Union (EU) system - 28 member states, 24 official languages - the privileging of English can be seen as involving linguicism in largely covert ways, through laissez-faire policies that allow market forces free rein and strengthen English (Phillipson 2003, 2016b).

The international expansion of English has been predicted and promoted regularly by leaders on both sides of the Atlantic over the past 200 years. In October 1934 the Carnegie Foundation sponsored a conference in New York on 'The use of English as a world language'. It brought together British and American teachers of English with extensive Asian experience, people who were a major

\footnotetext{
11 The European occupiers of Mexico in 1519 destroyed heathen idols (Diaz 1963) with the same barbarity as the Taleban and ISIS destroy artefacts in Afghanistan and the Middle East. The US and its willing partners have perpetrated well-documented crimes of cultural genocide and cultural cleansing in Iraq, with massive consequences for local languages (Abdul Haq al-Ani and Tariq al-Ani 2015).

12 Terra nullius in international law signifies land to which no-one holds legal title. My use of cultura nullius and lingua nullius does not detach what is referred to from its original owners or inhabitants, i.e. US culture and the English of the UK and USA. Cultural and linguistic expansion do not occupy vacant space but are necessarily in competition and conflict with local practices. The culture and language are no more empty than the land of the ancestral inhabitants of nonEuropean continents was. They are vulnerable in the same way as bastard offspring have been treated as filius nullius (Kayman 2009).
} 
influence on textbook production, dictionaries, and the theorisation of language teaching. The goal of 'spreading English "as a world language" on a basis of UK-US collaboration' (Phillipson 2009: 112, italics added) led to US funding of activities on both sides of the Atlantic in the 1930s and again in the 1950s with the creation of the English Language Teaching profession and departments of applied linguistics. These are now a billion-pound/dollar industry in 'Englishspeaking countries'. This label is a misnomer for countries that have always been multilingual, and sanitises the reality of a history of language oppression and current hegemony. In the worldwide English teaching business, power is still in the $21^{\text {st }}$ century held firmly by its authorities in the USA and UK (Kumaravadivelu 2016). It is self-delusion if the profession's academics believe they act in a politically uncommitted way (Bourdieu 2010).

US influence on academia in continental Europe and the UK was strong throughout the entire inter-war period. US foundations dispensed research funding, and influenced the way that many academic disciplines such as medicine, anthropology, economics, and sociology were fashioned (Arnove 1982). In the natural sciences, US funding and influence facilitated the shift from German to English as the dominant lingua academica.

In 1941 Churchill and Roosevelt signed an Atlantic Charter that was a blueprint for what should happen once fascism was defeated (Phillipson 2009: 118). At Roosevelt's prompting, Churchill was awarded an honorary doctorate at Harvard in 1943. The five key themes of his acceptance speech were UK/US unity, military collaboration, plans for global peace-keeping, US/UK global dominance, and global English ${ }^{13}$.

This gift of a common tongue is a priceless inheritance, and it may well some day become the foundation of a common citizenship. I like to think of British and Americans moving about freely over each other's wide estates with hardly a sense of being foreigners to one another. But I do not see why we should not try to spread our common language even more widely throughout the globe and, without seeking selfish advantage over any, possess ourselves of this invaluable amenity and birthright.

Churchill was well aware that 'selfish advantage' was central to the British Empire (Darwin 2009: 268). His claim of a 'birthright' to expand English worldwide is classic imperialist rhetoric.

The five strands in Churchill's address at Harvard led him to conclude:

Such plans offer far better prizes than taking away other people's provinces or lands or grinding them down in exploitation. The empires of the future are the empires of the mind.

Churchill accurately anticipated how different the world would be after World War Two, and acted to ensure the promotion of English worldwide. The mantras of our current empire of the mind are the knowledge economy and lifelong learning, both of them promoted by the OECD and the European Union (EU). It is

\footnotetext{
${ }^{13} \mathrm{http}$ ///www.winstonchurchill.org/learn/speeches/speeches-of-winston-churchill/118-theprice-of-greatness.
} 
arguable that Churchill's ideas have had a decisive influence on the modern world, with the UK as a junior partner to the US in the post-1945 neoimperial world and the transition into corporate and military neoliberalism.

After 1945, English became the dominant language of international relations, trade, banking, scientific scholarship, and popular culture, not by chance but through American leadership. The groundwork was laid in think tanks funded by US foundations during the war, and implemented in the Bretton Woods institutions, the UN, World Bank, IMF, NATO and countless other ways. This was a deliberate US strategy: 'The whole world should adopt the American system. The American system can survive in America only if it becomes a world system' (President Truman 1947, cited in Pieterse 2004: 131). Barack Obama echoed this theme on 28 May 2014: 'Here's my bottom line: America must always lead on the world stage'14.

Churchill's total faith in USA corporate and finance capitalism has been shared by all subsequent British Prime Ministers. The Margaret Thatcher Center for Freedom at the Heritage Foundation in Washington DC ${ }^{15}$ has as its goal the promotion of US/UK dominance worldwide. English, the 'common language', has been integral to this task, with the Establishment (leading bankers, corporate directors, politicians, and media barons) on both sides of the Atlantic implementing since 1970 a neoliberal agenda that has mainly benefited the wealthy and intensified inequality (Harvey 2005, Klein 2007, Jones 2015). The expansion of English worldwide has been a key constituent of British and American policy since the 1940s (Phillipson 1992, 2009). Terra nullius, American empire, and linguistic imperialism co-articulate.

\section{From American cultura nullius to English as a lingua nullius}

In the cultural cold war, all western European countries experienced massive efforts by the USA to project Hollywood, to influence intellectuals, reading habits, and cultural and political life in general (Saunders 1999, Wagnleitner 1994). McDonaldisation (as defined by Hamelink 1994 and Ritzer 2011) penetrated academia, the business world, the media, lifestyles and entertainment in countless ways. Neoliberal economic principles dovetail with cultural norms. American consumerist capitalism is projected as a cultura nullius of universal relevance, a necessity in the modern world (Kayman 2004). A case in point is the mushrooming of business schools worldwide: of a total of 16,000, half are in the US and one-third in Europe. After expansion in India and China, Africa is 'The new frontier for international business schools', with the likelihood of this being a new 'colonial frontier' of academic and economic imperialism ${ }^{16}$, and even greater use of English.

In school education the frontier is well established, with the mushrooming of English-medium education and the increasing privatisation of education, which is in conflict with the human right to free education (Skutnabb-Kangas and Dunbar 2010: 14-22). 'Global' English is a project to establish English as the

\footnotetext{
14 https://www.whitehouse.gov/the-press-office/2014/05/28/remarks-president-unitedstates-military-academy-commencement-ceremony.

15 http://www.thatchercenter.org.

16http://www.universityworldnews.com/article.php?story=20150421162549400. Wachira Kigotho, 24 April 2015 Issue No:364.
} 
language of neoliberal empire serviced by global finance whatever the consequences for other cultures and languages. Consolidating English in school systems worldwide is a major constituent of this project, with the British Council both master-minding the project and, paradoxically, making money out of it, as its Annual Reports and Corporate Plans make clear ${ }^{17}$. Most of the parastatal's budget derives from teaching and examining English and educational consultancies.

There is a boom in the market for English learning products and know-how, for fee-paying 'international' schools, for English-medium universities, for English ever earlier in 'basic' education (in conflict with principles of mothertongue based multilingual education that UNESCO advocates), and for 'native speaker' teachers (Bunce et al, eds. 2016). This affects former colonies in Africa and Asia, and the countries of 'informal' empire in Latin America and the Middle East. Pearson, the transnational publisher with a foot in many educational doors worldwide, has been denounced for its involvement in privatizing education in the global South, for which the British 'foreign aid' department provides funding ${ }^{18}$. Other publishers, Macmillan and Oxford University Press, have been convicted of bribery when ensuring the place of their textbooks in education in east African countries ${ }^{19}$. 'Global' education is seen as a market opportunity rather than a human good.

The British Council's promotion of English has also expanded as a result of the globalization of NATO (Nazemroaya 2012) after the implosion of the Soviet Union. This is marketed as English teaching for 'peace-keeping' in central Asia and former Warsaw Pact countries (Woods 2006, Templer 2016), as well in the Middle East and North Africa ${ }^{20}$. US military activity is being entrenched in much of Africa and Asia. The shock treatment imposed on Iraq involved the destruction of Iraqi higher education and US-led efforts to restructure education from top to bottom by Americans with no familiarity with the Arab world (Klein 2008, Kabel 2016). Among the direct beneficiaries are higher education institutions in the UK, to which Iraqis are sent for training, and the symbiotic English teaching business, teaching materials, language schools, consultants, etc. Linguistic and educational neoimperialism follow in the wake of invasion.

On 29 July 2013 the British government announced a 'New push to grow UK's $£ 17.5$ billion education exports industry' to ensure that 'British schools, universities, colleges and education businesses continue to stay ahead in the global education market - worth almost $£ 3$ trillion annually.' One goal of this 'export industry' is to attract '90,000 extra overseas university students by 2018 '.

The British Council spearheads the expansion of English learning worldwide through a wide range of activities. Its determination to influence education systems worldwide is of even greater significance than what is happening in

\footnotetext{
17 www.britishcouncil.org.

18 http://www.ipsnews.net/2015/04/push-to-privatise-education-in-global-south-challenged/.

${ }^{19}$ http://www.bloomberg.com/news/articles/2011-07-22/macmillan-publishers-must-pay-18million-for-africa-corruption. http://www.worldbank.org/en/news/press-

release/2012/07/03/world-bank-sanctions-oxford-university-press-corrupt-practicesimpacting-education-projects-east-africa

20 Details are often provided in the monthly online

http://mag.digitalpc.co.uk/Olive/ODE/ELGAZETTE/.
} 
higher education. The marketization of English is led by a 'Director of English and Exams' who is presented on the BC website as follows: 'Mark Robson is a member of the British Council's Executive Board. Much of his business career has been in international consumer product marketing and sales, including at the market research agency MORI, Colgate-Palmolive, and the US conglomerate Georgia-Pacific.' These qualifications are apparently needed for the commodification of English and for marketing education through the medium of English in an organization that defines itself as 'the UK's international organisation for cultural relations and educational opportunities' and is formally a charity ${ }^{21}$.

English is marketed as a language that everyone needs and that all should learn. This is another of the myths of global English. It is blithely proclaimed as the lingua franca for humanity, as though it corresponds to universal needs. English is ascribed the role of a lingua nullius, reinforcing the myth and injustices of terra nullius and an environmentally destructive cultura nullius. In the USA, Canada, and Australasia, terra nullius entailed the implantation of English for all purposes in richly diverse societies, English as the default lingua nullius. This national scenario is now being exported worldwide.

British Council policy texts, which are used in advising governments worldwide, describe English as 'the world's common language', which demographically is patent nonsense ${ }^{22}$. It is BC policy to claim that 'development' is dependent on proficiency in English (Howson 2013), an equally selective, false statement. It projects 'world' English or 'global' English as a universal need (Graddol 2006: 96-97, 106-9). 'English is now seen as a "basic skill” which all children require if they are fully to participate in 21 st century civil society. (...) It can now be used to communicate to people from almost any country in the world (...) We are fast moving into a world in which not to have English is to be marginalised and excluded' (Graddol 2010: 10).

This is straight English as a lingua nullius discourse that makes invalid claims and conceals the vested interest of the British in promoting English worldwide. No evidence is adduced for the claims or who underwrites them. The argument that you can communicate in English with 'people from almost any country in the world' is flawed. You don't get far in Latin America, southern Europe, most of Africa, the Middle East or Asia - even in India - with English outside elite circles and tourist sites. Even in Scandinavia, proficiency in communication in English above a crude spoken level is not widespread. Contrary to what Coleman, cited initially, asserts, the expansion of English in higher education in Europe consists almost invariably of English being added to national language repertoires rather than replacing them (Gregersen 2014, Phillipson 2015). While English is of major importance for the global economy, assuming that it is so 'basic' that it is a

\footnotetext{
21 www.britishcouncil.org. When Educational Testing Services of Princeton NJ (famous outside the US for the TOEFL test of language proficiency) established a European office, its first director was recruited from the pharmaceutical world. It now has six 'global offices, one of which is for 'Europe, the Middle East, and Africa', reflecting trends of the past 15 years. Its 'Global Institute' is all about marketing its US services worldwide. Its explicit goal is to influence and be used throughout education worldwide, www.ets.org.
}

${ }^{22}$ For data on the world's languages, see www.ethnologue.org. 
requirement for economic success is contradicted by the fact that the economies of China, Japan and Korea succeed through using local languages in basic education, as do continental European countries.

The currently fashionable English as a Lingua Franca (ELF) movement, the study of the use of English by people for whom it is not a first language, is a clear instance of promoting English as a lingua nullius, since ELF is seen as divorced from societal power, a form of communication in which anything (linguistic) goes, and native speaker norms are considered irrelevant. This empiricist exercise is theoretically and methodologically flawed, as many articles have demonstrated (e.g. O'Regan 2014).

It is also more than likely that most scholars are creative when thinking in their mother tongue, and that for continental Europeans, Latin Americans, or Asians, this can be combined with acquiring proficiency in English as a lingua academica, an additional rather than a subtractive language, at some point in their professional career. This is what Trabant and Bourdieu, cited earlier, advocate, proficiency in English without one's primary linguistic competence being downgraded, without being brainwashed.

British Council activity in promoting English is ubiquitous. Its Chief Executive asserts in the Annual Report 2009-10: 'English Next India ${ }^{23}$ tells us that from education to the economy, from employability to social mobility, the prospects for India and its people will be greatly enhanced by bringing English into every classroom, every office and every home' (italics added). This brazen neoimperial Churchillian idea is in conflict with principles of social justice in India, as articulated by Gandhi (2010), Tagore, and Nehru. More recently Amartiya Sen, the Nobel Prize for economics laureate, deplores current Indian policies and provides a rationale for more equitable policies that could enable the needs of the entire population of India to be met (Drèze and Sen 2014) ${ }^{24}$.

The British arguments are a re-run of the imperialism of the colonial age, as can be seen if one compares the bible of British colonial language policy, a Minute by Lord Macaulay, a spin doctor in India, and a policy document by an adviser to the British Council, David Graddol. The overall thrust in the two texts is fundamentally similar (Phillipson 2016a):

\begin{tabular}{|l|l|}
\hline \multicolumn{1}{|c|}{ Macaulay's Minute 1835 } & Graddol's English Next India 2010 \\
\hline $\begin{array}{l}\text { It denigrates and stigmatizes the } \\
\text { local. }\end{array}$ & $\begin{array}{l}\text { Indian learning of English is } \\
\text { inadequate. }\end{array}$ \\
\hline $\begin{array}{l}\text { It glorifies Western culture and } \\
\text { English. }\end{array}$ & $\begin{array}{l}\text { English is the key to success in the } \\
\text { modern world. }\end{array}$ \\
\hline $\begin{array}{l}\text { It rationalizes the asymmetrical } \\
\text { relationship between colonizer and }\end{array}$ & $\begin{array}{l}\text { The UK has the solution to India's } \\
\text { language in education problem. }\end{array}$ \\
\hline
\end{tabular}

\footnotetext{
23 A follow-up to Graddol 2006.

${ }^{24}$ Drèze and Sen's book does not cover language policy, probably because of lack of familiarity with the research on bilingual education. Sen's focus on capability deprivation correlates precisely with how English-medium education in India impacts on children (Mohanty and Skutnabb-Kangas 2013).
} 


\begin{tabular}{|c|c|}
\hline colonized. & \\
\hline $\begin{array}{l}\text { A British intellectual can decide } \\
\text { matters. }\end{array}$ & $\begin{array}{l}\text { A single expert from the UK can } \\
\text { cover the issues. }\end{array}$ \\
\hline $\begin{array}{l}\text { It conceals the economic interest of } \\
\text { the colonizers. }\end{array}$ & $\begin{array}{l}\text { The potential benefits to the UK } \\
\text { economy are not mentioned. }\end{array}$ \\
\hline $\begin{array}{l}\text { It fails to refer to the reality of } \\
\text { British military occupation of India. }\end{array}$ & $\begin{array}{l}\text { Geostrategic political and military } \\
\text { interests are not mentioned. }\end{array}$ \\
\hline
\end{tabular}

Advocates of global English promote British interests worldwide, perpetuate linguistic imperialism, and use myths about English being necessary for all. They condone linguistic capital dispossession. The ideology and advocacy of English as a lingua nullius are integral to these processes.

\section{Linguicism and linguistic capital accumulation or dispossession}

The discourses and economic pressures behind English are currently being both strengthened and resisted. English may be added to people's linguistic repertoires, when there is investment in the learning and use of the language, which can be seen as linguistic capital accumulation. By contrast, if linguicism is in force, and if English is being learned with other languages not being maintained and used, this can be considered linguistic capital dispossession.

Individuals opt for the dominant language because it is felt that this linguistic capital will serve their personal or professional interests best. Individual agency and decision-making reflect a range of societal forces and ideologies, with education as a key site constraining individual freedom and choice ${ }^{25}$. Linguistic imperialism involves a mix of push and pull factors, local and external pressures. When language shift is subtractive, and if this affects a group and not merely individuals, there are serious implications for other languages. If domains such as business, the home, or scholarship are 'lost', what has occurred is in fact linguistic capital dispossession. There are agentive forces behind the language shift, causal factors that lead to an increased use of English.

At some Scandinavian universities, there are higher financial rewards for books or articles published in English than in a national language. Promotion prospects may also be determined by this linguicist practice. For several decades there has been concern in these countries that the increased use of English may well be occurring at the expense of national languages. Inter-Nordic collaboration has resulted in the Nordic countries being formally committed to maintaining the vitality of national languages while promoting competence in international languages, particularly English ${ }^{26}$. Since government-level language

\footnotetext{
${ }^{25}$ See the typology of fifteen factors contributing to the increased use of English in Europe, grouped as structural and ideological, Phillipson 2003: 64-65.

${ }^{26}$ A Declaration on a Nordic Language Policy was approved in 2006 by the Nordic Council of Ministers, and promulgated in Danish, Faeroese, Greenlandic, Finnish, Icelandic, Norwegian, Saami, Swedish, and English. The document specifies the language rights of all residents in a Nordic country, and sets out goals for language policy. It encourages key institutions to develop
} 
policy in this area is being made explicit, it is positive that language policy is not merely being left to market forces and improvisation. The underlying thinking is both/and rather than either/or. The focus is not on a single medium of instruction, but a combination.

There has likewise been a good deal of reflection in Germany, leading to a declaration by German University Rectors that aims at maintaining the vitality of German as a scholarly language, while also ensuring proficiency in other languages for various purposes ${ }^{27}$. A major conference produced a detailed analysis of issues and recommendations (Oberreuter et al, eds., 2012), which aim at strengthening language policy so as to avoid the doomsday scenario of Meyer, cited earlier. Such efforts aim at ensuring that German remains a full language of scholarship in all relevant fields and in scientific teaching and popularisation.

In both the Nordic and German cases, English is being learned and used additively, as an enlargement of personal repertoires and national competence. This is all for the good. The challenge of ensuring a harmonious balance between English and national languages in higher education is being addressed throughout Europe (Dimova, Hultgren, and Jensen, eds., 2015). English in academic work, written and spoken, is not a lingua franca in the original sense of a limited, hybrid form of language for specific trading functions. Academic English has to be internationally intelligible, which presupposes that it is grounded in the English of authoritative dictionaries and syntax. English as a lingua academica should function alongside academic literacy in national languages.

One negative consequence though of the priority given to English, and the massive exposure of young people to English outside school, is a significant drop in the study of other foreign languages, even when these languages are important for many reasons, some instrumental (exports, EU collaboration), some of historical, intellectual, and present-day intercultural importance.

Elites in former colonies are increasingly opting for English-medium education at all levels, and in their private and professional lives. All education in Singapore is exclusively through the medium of English, with national languages as subjects only. English is the language of power, as in other former colonies, with the consequence that more than half the population of Singapore use English as the home language (Pakir 2007: 197). They have more limited competence in other languages as well as in Singlish, a hybrid creole for informal purposes. This has been a process of subtractive language learning, a replacement of local languages by English.

The Singapore case follows the logic of the country being a creation of colonialism, and its post-independence rulers appreciating that its economic and linguistic well-being would thrive best by its integration into global finance and commerce. When Singaporeans invest in acquiring competence in English through organising a gradual shift from Asian languages into English, this represents linguistic capital accumulation in an important international language. But when government and family policies in effect entail reducing and ultimately eliminating competence in local, national languages, this simultaneously represents linguistic capital dispossession. The external and

long-range strategies for choice of language, the parallel use of languages, and language instruction, www.norden.org.

27 Resolution of the German Rectors' Conference of 22 November 2011, in English at www.hrk.de. 
internal forces that trigger this change in the local language ecology can be identified.

Similarly, if Germans or Swedes use English as a language of scholarship, comparable structures and processes are at work: this may relate only to reading and disseminating research (a century-old practice) but increasingly entails lecturing in English, and may involve the production or generation of ideas in English as well as in the mother tongue. Whether there is a healthy addition to people's linguistic repertoire, linguistic capital accumulation or, at the other end of a continuum, the gradual subtraction and elimination of national languages in research, teaching, and publication, linguistic capital dispossession, is an empirical question that needs exploration in any given context.

Revealing research has been undertaken in Swedish universities on a range of parameters that influence how bilingual academic literacy is being successfully achieved in Swedish and English (Airey 2015). This research highlights the relevance of key pedagogic variables in a northern European context, whereas in universities in the rest of Europe the increased use of English is being implemented less effectively (Dimova, Hultgren and Jensen, eds. 2015).

We should all be frightened of English as a lingua tyrannosaura (Swales 1997), linguistic cannibalism (glottophagie, Calvet 1974). English has in fact functioned as a lingua frankensteinia on several continents, English as a voracious lingua nullius. It is false therefore to refer to the extinction of languages in imperial contexts as language death, which implies a natural, agentless process, since language extinction has typically been an explicit policy of the dominant power (Skutnabb-Kangas and Phillipson 2010).

Developments in the EU's management of language policy, many of them covert, exemplify how English is being structurally favoured. The Bologna process, the unification of European higher education systems, has systematically ignored language policy. Multilingualism and bilingual higher education have never been on the agenda, despite the EU rhetoric of strengthening multilingualism ${ }^{28}$. Effectively what this means is that internationalisation is conflated with using English, though the overall picture is still linguistically diverse. It is however fair to conclude that Bologna and its supplement, creating a single European research area, is in reality a market that strengthens English at the expense of other languages, as indicated in the analysis of Hans Joachim Meyer, cited initially, and as evidenced in many of the practices of the EU.

In the Directorate-General for Research of the European Commission, the regulations for applications state that one can submit in any of the EU's 24 official languages, but it is made abundantly clear that you will be doing yourself a disservice if the application is not in English ${ }^{29}$. This discriminates against scholars for whom the main language of scholarship is a Slavic, Romance, or Finno-Ugric language. The policy is linguicist.

The 'High Level' group on the modernisation of higher education, in their Report to the European Commission in June 2013 ${ }^{30}$, in Recommendation 12, endorses English as the language of internationalisation, while also making a

\footnotetext{
${ }^{28}$ This reality is confirmed in the latest implementation report, European Commission/EACEA/Eurydice 2015.

${ }^{29}$ See http://www.welcomeurope.com/extract-comprehensive-guideline.html.

30 http://ec.europa.eu/education/library/reports/modernisation en.pdf.
} 
token nod in the direction of competence in a second foreign language. Only one language is seen as an international lingua academica. This is an example of what may sound pragmatically sound, but which fundamentally represents yet another instance of the linguicist favouring of English, without consideration of the implications for other languages, or of how national languages serve as democratic instruments for creating a well-informed public.

English is now also the default language in-house in EU institutions, supplanting French at the top of the linguistic hierarchy. This development led the Délégation nationale à la langue française et aux langues de France, in its Annual Report of 2006 to conclude that 'there is a tendency for French to become a language for translating into but not for producing ideas' 31 . In other words a monolingual culture and mindset within EU institutions affects both content and form. There are many factors that account for the EU not pursuing more dynamic and egalitarian language policies (Phillipson 2003, 2011b, 2016b).

Many scholars under-estimate the challenges that the expansion in the use of English signifies for other languages. There are major faults in the work of advocates of English as the sole unifying language for all Europeans and as an exclusive language of EU law like Philippe Van Parijs (see Phillipson 2012a, May 2015). Likewise Jim Coleman, cited initially, misrepresents what is happening in European higher education (Phillipson 2015a). Our critical antennae need to be hoisted when eminent scholars like David Crystal and Nicholas Ostler neglect the political economy of English and implicitly condone linguistic imperialism (for reviews, see Phillipson 1999 and 2011a), or when Jan Blommaert, in his sociolinguistics of globalization ignores many of the aspects that connect language and power (Phillipson 2012b). Linguicism co-articulates with class, racism, and sexism, and needs to be resisted, like all mechanisms that condone injustice and inequality.

\section{Concluding with a look forward}

Churchill was awarded a second honorary doctorate, by the University of Copenhagen in Denmark in 1950. The declared reasons for granting the award were Churchill's accomplishments as a historian (he was awarded the Nobel Prize for Literature in 1953) and his key role in the Second World War. This ultimately ensured the end of five years of German occupation of Denmark. In his Copenhagen acceptance speech Churchill had a completely different focus from Harvard in 1943, and made profound observations about the role of the university that are extremely relevant in the $21^{\text {st }}$ century:

The first duty of a university is to teach wisdom, not to train, and to confirm character and not impart technicalities. We want a lot of engineers in the modern world, but we do not want a world of engineers. We want some scientists, but we must make sure that science is our servant and not our master... No amount of technical knowledge can replace the comprehension of the humanities or the study of history and philosophy.

\footnotetext{
31 The French is concise and subtle: '... le français tend à devenir une langue de traduction et non plus de conception'.
} 
The advantages of the nineteenth century, the literary age, have been largely put aside by this terrible twentieth century with all its confusion, exhaustion, and bewilderment of mankind. This is a time when a firm grip on all the essential verities and values of humanity and civilization should be the central care of the universities of Europe and the world.

This is an endorsement of the academic freedom that Bourdieu advocates, the need for creative, independent, critical scholarship. Alas, this humanist vision of the role of universities has been gravely undermined in recent decades. Following the example of the USA and the UK, and with active EU support, governments worldwide are increasingly forcing universities to graduate technocrats and technicians who are ignorant of 'history and philosophy', and no longer seek wisdom or independent thought. Academic freedom and university autonomy are severely constrained. Critical scholarship is rare and generally submerged under positivistic, empiricist blankets or intellectual theorizing or fantasizing. Churchill's engineers have been replaced by doctrinaire economists and mediocre politicians committed to neoliberalism ${ }^{32}$. The constitutional treaty of the EU endorses neoliberalism. Universities are expected to service it. The empires of the present, in which English plays a decisive role, promote inequality and injustice.

Maintaining the vitality of all languages entails avoiding being brainwashed either at the micro level of concepts and discourse patterning originating in English or at the macro level of unquestioning faith in the structures and ideologies that strengthen English and neoliberalism and its devastating consequences.

The challenge for language policy is to situate English in the overall context of a world that is racked by widespread crises, environmental, economic, political, military, and social. Along all these parameters the Americanisation effort to impose its system worldwide is in deep trouble. The European integration project has had very uneven results as well as poor legitimacy: undemocratic management, euro destabilisation, economic inequality, citizens with limited faith in EU institutions, political disaffection nationally and internationally, inability to agree on refugee policy. Language policy in the EU is left to market forces that currently favour English. Universities are increasingly subject to corporate pressures and control. Many language policies worldwide are linguicist overtly or covertly.

Whether the current dominance of English will continue for more than a decade or two is an open question. China has benefited massively from the globalisation of recent decades. It is investing in strengthening its economy worldwide, its military capacity, and party control, while also promoting Chinese worldwide through establishing Confucius Institutes in comparable ways to Anglo-American policies for strengthening English throughout of the post-1945 period. Soft power is a key foreign policy instrument, and extremely effective if it

\footnotetext{
32 A contemporary of Churchill, the distinguished economist Keynes, denounced love of money as a pathological evil, and recommended that economists 'should get themselves thought of as humble, competent people, on a level with dentists' (Keynes 2015: 75-86, written in 1930). For Keynes the ideal economist combined the talents of the mathematician, historian, statesman, and philosopher (ibid: xxvi).
} 
can be projected as divorced from economic, financial, and military power, as both English and Chinese have tended to be.

Scholars using English run the risk of being in the same ambivalent position as Churchill, consolidating the power of English while wishing to ensure that universities only serve humane, moral, culturally and politically enlightened purposes. Academics need to analyse whether they are complicit in a system that serves the $1 \%$ rather than all of humanity.

The monolingualism of much linguistic, applied linguistic, and sociolinguistic research in the USA and UK, and indeed of research in general in countries in which English is dominant, may serve to consolidate English in covert hegemonic ways that we constantly need to be alert to. It may serve to promote English as a lingua nullius in linguicist ways.

Anna Wierzbicka's book Imprisoned in English. The hazards of English as a default language (2014) confirms that we need to be constantly aware of the risk of being brainwashed by English. Her analysis operates exclusively at the micro level whereas my concern in this article is mainly with the macro level, historical factors, the forces and myth-making behind the expansion of English worldwide. Wierzbicka and Trabant insist that even when English is used as a lingua academica, it builds on the semantics and grammar of how English evolved in English-using cultures. English as a lingua nullius operates in tandem with English as a lingua economica, the vehicle of neoliberalism and global finance, English as a lingua cultura, Hollywood, McDonalds et al, a lingua bellica, the language of the US military and its acolytes, and English as a lingua divina, when Christian missionaries use English teaching worldwide as a platform for conversion (Wong and Canagarajah, eds., 2009).

The assumption that English is the sole language of globalisation, and in everyone's interest is patently false. Lingua nullius arguments and the notion that English is already global are comparable to the claim by Margaret Thatcher that There Is No Alternative to neoliberalism (McMurtry 2002: 19) and Tony Blair claiming that this system is 'universal' (ibid.: 21). Neoliberalism is still alive and kicking, despite the financial collapse of 2008 (Jones 2015), the ongoing euro crisis, and failure to adopt more socially just alternative financial and economic measures. Advocates of English for all, nationally and internationally, are false prophets. The argument that English is 'owned' by all who use it ignores the inequalities that are generated by and through English, as can be seen clearly in the way English is currently favoured in education systems in many countries, in former colonies, and in regional bodies like the EU, the African Union, and the Association of South East Asian Nations. English is not a panacea. It need not be a pandemic, provided linguistic capital accumulation does not entail the dispossession of linguistic capital invested in other languages.

\section{References}

al-Ani, A. H. \& al-Ani, T. (2015). Genocide in Iraq, volume 2.The obliteration of a modern state. Atlanta, GA: Clarity Press.

Airey, J. (2015). From stimulated recall to disciplinary literacy: Summarizing ten years of research into teaching and learning in English. In Dimova, S., Hultgren, A. K., \& Jensen , C. (Eds.) 2015. English-medium instruction in higher 
education in Europe (pp. 157-176). Berlin: Mouton de Gruyter

Arnove, R. F. (ed.) (1982). Philanthropy and cultural imperialism. The foundations at home and abroad. Bloomington: Indiana University Press.

Bourdieu, P., de Swaan, A., Hagège, C., Fumaroli, M., \& Wallerstein. I (2001). Quelles langues pour une Europe démocratique? Raisons politiques 2, 41-64.

Bourdieu, P. (1989). La noblesse d'état. Grandes Écoles et esprit de corps. Paris: Les Éditions de Minuit.

Bourdieu, P. 2010. Sociology is a martial art. Political writings by Pierre Bourdieu. Ed. G. Sapiro. New York: The New Press.

Bunce, P., Phillipson, R., Rapatahana, V., \& Tupas, R (Eds.) (2016). Why English? Confronting the Hydra. Bristol: Multilingual Matters.

Calvet, L.-J. (1974). Linguistique et colonialisme: Petit traité de glottophagie. Paris: Payot.

Coleman, J. A. (2006). English-medium teaching in European higher education. Language Teaching, 39, 1-14.

Darwin, J. (2009). The empire project. The rise and fall of the British world-system 1830-1970. Cambridge: Cambridge University Press.

Diaz, B. (1963). The conquest of New Spain. Harmondsworth: Penguin.

Dimova, S., Hultgren, A. K., \& Jensen , C. (Eds.) 2015. English-medium instruction in higher education in Europe. Berlin: Mouton de Gruyter.

Dörnyei, Z. (2009). The English language and the word of God. In Wong, M.S. \& Canagarajah, S. (Eds.), Christian and critical English Educators in Dialogue. Pedagogical and ethical dilemmas (pp. 154-157). London \& New York: Routledge.

Drèze, J. \& Sen, A. (2014). An uncertain glory. India and its contradictions. London: Penguin.

Errington, J. (2008). Linguistics in a colonial world. A story of language, meaning, and power. Malden, MA: Blackwell.

European Commission/EACEA/Eurydice (2015). The European Higher Education Area in 2015: Bologna Process Implementation Report. Luxembourg: Publications Office of the European Union.

Gandhi, M. K. (2010, originally 1909). M. K. Gandhi's Hind Swaraj. A critical edition, ed. S. Sharma and T. Suhrud. New Delhi: Orient Blackswan.

Graddol, D. (2006). English next. London: British Council.

Graddol, D. (2010). English next India. London: British Council.

Gregersen, F. (ed.) \& 13 contributors (2014). Hvor parallelt. Om parallelspråkighet på Nordens universiteter. København: Nordisk Ministerråd. http://www.norden.org/en/publications/publikationer/2014-535.

Hamelink, C. (1994). Trends in world communication: on disempowerment and self-empowerment. Penang: Southbound and Third World Network.

Harvey, D. (2005) [2003]. The new imperialism. Oxford: Oxford University Press.

Howson, P. (2013). The English Effect. The impact of English, what it's worth to the UK and why it matters to the world. http://www.britishcouncil.org/sites/britishcouncil.uk2/files/englisheffect-report.pdf, 2013, accessed 28 February 2015.

Jones, 0. (2015). The Establishment. And how they get away with it. London: Penguin Random House.

Kabel, A. (2016). Afterword: Decentering the Hydra: Towards a more equitable linguistic order. In Bunce et al (Eds.). 
Kayman, M. A. (2004). The state of English as a global language: communicating culture. Textual practice, 18/1, 1-22.

Kayman, M. A. (2009). The lingua franca of globalization: "filius nullius in terra nullius", as we say in English. Nordic Journal of English Studies 8/3, 87-115.

Keynes, J. M. (2015). The essential Keynes. Edited and with an Introduction by R. Skidelsky. London: Penguin Random House UK.

Klein, N. 2008 [2007]. The shock doctrine. The rise of disaster capitalism. London: Penguin.

Kumaravadivelu, B. (2016). The decolonial option in English teaching: can the subaltern act? TESOL Quarterly, 50/1, 66-85.

Locke, J. (1988, originally 1690). Two treatises of government. Cambridge: Cambridge University Press.

May, S. (2015). The problem with English(es) and linguistic (in)justice. Addressing the limits of liberal egalitarian accounts of language. Critical Review of International Political and Social Philosophy.

McMurtry, J. (2002). Value wars. The global market versus the life economy. London: Pluto.

Meyer, H. J. (2011). Bologna oder Harvard? Realität und Ideologie bei der deutschen Studienreform. Zeitschrift für Politik, 4, 51-62.

Mohanty, A. K. \& Skutnabb-Kangas, T. (2013). MLE as an economic equaliser in India and Nepal: mother tongue based multilingual education fights poverty through capability development and identity support. In Henrard, K. (Ed.), Socioeconomic participation of minorities in relation to their right to (respect for) identity (pp. 159-187). Leiden: Brill/Martinus Nijhoff.

Nazemroaya, Mahdi Darius (2012). The globalization of NATO. Atlanta, GA: Clarity Press.

Oberreuter, H., Krull, W., Meyer, H. J., \& Ehlich, H. (Hg.) (2012). Deutsch in der Wissenschaft. Ein politischer und wissenschaftlicher Diskurs. München: Olzog Verlag.

O’Regan, J. P. (2014). English as a lingua franca: an immanent critique. Applied Linguistics, 35/5, 533-552.

Pakir, A. (2007). Bilingual education in Singapore. In J. Cummins \& N. H. Hornberger (Eds.), Bilingual education. Encyclopedia of Language and Education, $2^{\text {nd }}$ edition, Volume 1 (pp. 191-203). New York: Springer.

Phillipson, R. (1992). Linguistic imperialism. Oxford: Oxford University Press.

Phillipson, R. (1999). Voice in global English: unheard chords in Crystal loud and clear. Review article on 'English as a global language' by D. Crystal. Applied Linguistics, 20:2, 288-299.

Phillipson, R. (2003). English-only Europe? Challenging language policy. London: Routledge.

Phillipson, R. (2009). Linguistic imperialism continued. New York: Routledge, and Delhi: Orient Blackswan.

Phillipson, R. (2011a). Book review of N. Ostler, The last lingua franca. English until the return of Babel (HarperCollins, 2011), Language Policy, 11/2, 197200.

Phillipson, R. (2011b). The EU and languages: diversity in what unity? In A. L. Kjær \& S. Adamo (Eds.), Linguistic diversity and European democracy (pp. 5774). Farnham: Ashgate.

Phillipson, R. (2012a). Review Essay. Languages, genocide, and justice in the 
European integration process. Review article on Indigenous Children's Education as Linguistic Genocide and a Crime against Humanity? A Global View (Skutnabb-Kangas \& Dunbar) and Linguistic Justice for Europe and for the World (van Parijs). Journal of Contemporary European Studies, 20/3, 377-381. Phillipson, R. (2012b). How to strengthen the sociolinguistics of globalization: A review article based on challenges in The sociolinguistics of globalization by J. Blommaert. Critical Discourse Studies, 9(4): 407-414.

Phillipson, R. (2015). English as threat or opportunity in European higher education. Dimova, S., Hultgren, A. K., \& Jensen, C. (Eds.), English-medium instruction in higher education in Europe (pp. 19-42). Berlin: Mouton de Gruyter.

Phillipson, R. (2016a). Promoting English: Hydras old and new. In Bunce et al (Eds.).

Phillipson, R. (2016b). Linguistic imperialism of and in the European Union. In Behr, H. \& Stivachtis, J. (Eds.), Revisiting the European Union as an empire (pp. 134-163). London: Routledge.

Pieterse, J. N. (2004). Globalization or empire. New York: Routledge.

Ritzer, G. (2011). The McDonaldization of society 6. Thousand Oaks, CA: Sage.

Saunders, F. S. (1999). Who paid the piper? The CIA and the cultural world war. London: Granta.

Skutnabb-Kangas, T (1988). Multilingualism and the education of minority children. In Skutnabb-Kangas, T. \& Cummins, J. (Eds), Minority education: from shame to struggle (pp. 9-44). Clevedon: Multilingual Matters.

Skutnabb-Kangas, T. (2000). Linguistic genocide in education - or worldwide diversity and human rights? Mahwah, NJ: Lawrence Erlbaum.

Skutnabb-Kangas, T. \& Dunbar, R. (2010). Indigenous children's education as linguistic genocide and a crime against humanity? A global view. Guovdageaidnu/Kautokeino: Galdu, Resource Centre for the Rights of Indigenous People.

Skutnabb-Kangas, T. \& Phillipson, R. (2010). The global politics of language: markets, maintenance, marginalization or murder. In Coupland, N. (Ed.), The Handbook of Language and Globalization (pp. 77-100). Malden, MA and Oxford: Wiley-Blackwell.

Swales, J. (1997). English as 'Tyrannosaurus Rex'. World Englishes 16 (3), 373382.

Templer, B. (2016). English Hydra as Invader on a post-communist 'new periphery'. In Bunce et al (Eds).

Trabant, J. (2012). Über die Lingua Franca der Wissenschaft. In Oberreuter, H., Krull, W., Meyer, H. J., \& Ehlich, H. (Hg.) (2012). Deutsch in der Wissenschaft. Ein politischer und wissenschaftlicher Diskurs (pp. 101-107). München: Olzog Verlag.

Wagnleitner, R. (1994). Coca-Colonization and the cold war. The cultural mission of the United States in Austria after the Second World War. Chapel Hill: University of North Carolina Press.

Wierzbicka, A. (2014). Imprisoned in English. The hazards of English as a default language. New York: Oxford University Press.

Wong, M. S. \& Canagarajah, S. (Eds.) (2009). Christian and critical English Educators in Dialogue. Pedagogical and ethical dilemmas. London \& New York: Routledge. 
Woods, P. (2006). 'The hedgehog and the fox': Two approaches to English for the military. In Edge, J. (Ed.) (re)locating TESOL in an age of empire (pp. 208-226). Basingstoke: Palgrave Macmillan. 